\title{
Studies on the Transport and Metabolism of Conjugated Bile Salts by Intestinal Mucosa *
}

\author{
Marc R. Playoust † and Kurt J. Isselbacher \\ (From the Department of Medicine, Harvard Medical School, and the Medical Services \\ [Gastrointestinal Unit], Massachusetts General Hospital, Boston, Mass.)
}

Bile salts have a central role in the digestion and absorption of fat in the intestinal tract. In addition, since the sterol nucleus is not further metabolized by mammalian cells, the bile salts represent the main excretory products of the body's cholesterol stores (1). The enterohepatic circulation of bile salts is well established, and upwards of $95 \%$ of the amount excreted through the bile duct is absorbed from the intestine for subsequent re-excretion by the liver (2). In vitro studies have shown an active transport mechanism to be present in the ileum of a number of species $(3,4)$; this site of absorption has been confirmed in vivo in the guinea pig and the dog $(5,6)$.

We have studied further aspects of the active transport of bile salts, choosing sodium taurocholate as a model for most of the work. We were unable to find evidence for hydrolysis of the conjugated bile salts during their active transport in vitro. Taurocholate absorption across everted gut sacs exhibted saturation kinetics and was reversibly inhibited by cholate and glycocholate. A striking finding was that at low or absent sodium ion concentrations in the medium, active transport is markedly inhibited. We have compared these effects with those of anoxia and of metabolic inhibitors such as dinitrophenol.

\footnotetext{
* Submitted for publication September 24, 1963; accepted November 14, 1963.

This work supported in part by U. S. Public Health Service grant A-3014 from the National Institutes of Health.

$\uparrow$ Work done during tenure of a fellowship from the Postgraduate Medical Foundation, University of Sydney. Present address : Department of Medicine, University of Sydney, Australia.
}

\section{Materials and Methods}

Commercial preparations of cholic acid, ${ }^{1}$ glycine, ${ }^{2}$ and taurine $^{3}$ were recrystallized twice before use. The purity of the cholic acid was checked by thin-layer chromatography on silicic acid by the two solvent systems described by Hofmann (7). Solvents employed were reagent grade and were not redistilled; ether was peroxide-free. 2,4-Dinitrophenol 3 (DNP) was recrystallized from water; other inhibitors were phloridzin 4 and ouabain. ${ }^{5}$

Sodium taurocholate was synthesized by the method of Norman (8). After evaporation, the reaction mixture was dissolved in dilute aqueous alkali and extracted with ether to remove residual tributylamine. The solution was then acidified and unreacted cholic acid extracted with chloroform. Further purification was carried out as described (8); however, when there was difficulty with the first recrystallization, a salting out procedure was also employed (9). The purity of the product was checked by melting point determinations and by thin-layer chromatography; chemical assay for any persistent contamination by cholate was carried out by the procedure described below.

Glycocholic acid was synthesized by the technique of Bergström and Norman (10) without modification. The purity of the glycocholate was determined by melting point determinations and thin-layer chromatography.

Radioactive conjugated bile salts were prepared from nonradioactive cholic acid and either glycine-1- $\mathrm{C}^{\mathbf{1 4} 6}$ or taurine- $S^{35}{ }^{7}$ The $S^{35}$-taurocholate was essentially radiochemically pure. On thin-layer chromatography of the synthesized $\mathrm{C}^{14}$-glycocholic acid, there was a contaminant with the mobility of glycodeoxycholate; this impurity could be removed by reverse-phase column chromatography (11). The absence of unreacted glycine-1- $C^{14}$ was demonstrated by high voltage paper electrophoresis $(4,000 \mathrm{v})$ in formic acid and acetic buffer, $\mathrm{pH} 1.7$ (12).

1 Special enzyme grade. Mann Research Laboratories, Inc., New York, N. Y.

2 Mann Research Laboratories, Inc., New York, N. Y.

3 Eastman Organic Chemicals, Rochester, N. Y.

4 California Corp. for Biochemical Research, Los Angeles, Calif.

5 Eli Lilly and Company, Indianapolis, Ind.

6 New England Nuclear Corp., Boston, Mass.

${ }^{7}$ Nuclear-Chicago, Chicago, Ill. 
Cholic acid and its glycine and taurine conjugates were determined colorimetrically by the modified Pettenkofer method of Irvin, Johnston, and Kopala (13). Other bile salts are not measured by this method. The bile salt content of the wall of an everted gut sac was not usually measured directly but was estimated by subtracting the amounts recovered in the serosal and mucosal compartments from the quantity added initially to the incubation mixture. Taurine was determined by the method of Pentz, Davenport, Glover, and Smith (14).

Isotopic measurements were made in a Packard liquid scintillation spectrometer. Radioactive substances in aqueous solution were counted in a solution prepared by mixing 6.5 vol of $95 \%$ ethanol with 100 vol of dioxane containing $0.7 \%$ 2,5-diphenyloxazole (PPO), $0.01 \%$ bis2-(5-phenyloxazolyl) benzene (POPOP), and 5\% naphthalene. In other cases the radioactive product was dissolved in $4 \mathrm{ml}$ ethanol and mixed with $10 \mathrm{ml}$ of a toluene counting solution containing $0.3 \% \mathrm{PPO}$ and $0.01 \%$ POPOP.

Everted gut sac experiments. Female albino rats ${ }^{8}$ of weight $200 \mathrm{~g}$ and male golden hamsters ${ }^{9}$ weighing $150 \mathrm{~g}$ were fasted overnight before use in these experiments. Each animal was killed by a blow on the head, and everted sacs were prepared by the method of Wilson and Wiseman (15). When a sac was to be incubated in a medium of specific electrolyte composition, the gut was rinsed through with the same solution. Ileal sacs were taken from the small intestine just proximal to the ileo-cecal junction; jejunal sacs were from intestine distal to the ligament of Treitz. Unless otherwise specified, sacs from rats were $15 \mathrm{~cm}$ long and those from the hamster $10 \mathrm{~cm}$. In the case of the ileum, more reproducible results were obtained when only one sac was prepared from each animal.

The solution used on both serosal and mucosal sides was oxygenated Krebs-Ringer bicarbonate buffer (16) with a glucose concentration of 100 to $200 \mathrm{mg}$ per 100 $\mathrm{ml}$ and half the usual concentration of calcium. The complete ionic composition of the medium was as follows: $\mathrm{Na}^{+}, 143 ; \mathrm{K}^{+}, 5.9 ; \mathrm{Ca}^{++}, 1.27 ; \mathrm{Mg}^{++}, 1.18 ; \mathrm{Cl}^{-}, 125$; $\mathrm{HCO}_{3}^{-}, 25$; $\mathrm{HPO}_{4}^{-}, 1.18$; and $\mathrm{SO}_{4}=1.18 \mathrm{mM}$. Sodiumfree media were prepared by replacing all the $\mathrm{Na}^{+}$with $\mathrm{K}^{+}$or $\mathrm{Li}^{+}$; in experiments with intermediate concentrations of sodium, the substitute ion was always $\mathrm{K}^{+}$. Each sac was filled initially with $2 \mathrm{ml}$ of fluid with the same ionic composition as the mucosal medium; it was then immersed in $10 \mathrm{ml}$ of the incubation mixture containing the bile salt under study, either with or without an inhibitor. Note that bile salts were not present in the serosal fluid at the start of the incubation. The flasks were gassed continuously with a mixture of $95 \%$ oxygen and $5 \%$ carbon dioxide in a Dubnoff shaking incubator at $37^{\circ} \mathrm{C}$. Under these experimental conditions there was no significant fluid transfer from one compartment to the other. At the completion of the incubation each sac was blotted and its contents drained

8 Charles River Laboratories, Boston, Mass.

9 Dennen Animal Industries, Inc., Gloucester, Mass. into a tared vessel that was then reweighed; a sample of mucosal fluid was also taken for analysis. Protein was precipitated by the addition of $0.1 \mathrm{ml} 80 \%$ trichloroacetic acid or by boiling.

Mucosal homogenates. After removal of the intestine, the epithelial cells were gently scraped free as described previously (17), and $7 \mathrm{ml}$ of a solution of 0.125 $\mathrm{M}$ potassium phosphate buffer ( $\mathrm{pH} 7.0)$ was added for each gram of cells. The homogenates were prepared with a Potter-Elvehjem tissue grinder with a Teflon pestle. The homogenate was subsequently filtered through a double layer of absorbent gauze. The standard incubation mixture contained $0.5 \mathrm{ml}$ of the mucosal homogenate, $4 \mathrm{mg}$ glucose, $800 \mathrm{~m} \mu$ moles sodium taurocholate, and $1.5 \mathrm{ml} 0.125 \mathrm{M}$ potassium phosphate buffer, $\mathrm{pH}$ 7.0. Incubations were carried out for $90 \mathrm{~min}-$ utes at $37^{\circ} \mathrm{C}$ in air with occasional agitation and were terminated by immersion in boiling water for 10 minutes.

Analysis of taurocholate and cholate mixtures. When it was necessary to determine in the same specimen the concentrations both of taurocholate and of cholate, the following procedure was adopted. The sample was acidified and extracted three times with 2 vol of ether; the pooled ether extract was washed with a small volume of $0.1 \mathrm{~N}$ hydrochloric acid that was subsequently added to the water phase. After neutralization and evaporation at $40^{\circ} \mathrm{C}$ under a stream of air, an appropriate fraction of the residue was analyzed by the colorimetric method of Irvin and associates (13). Standard solutions were extracted in an identical way during each set of estimations. The recovery of taurocholate in the water phase was almost complete; that of cholate in the ether extract was approximately 85 to $90 \%$.

Estimation of specific activity of transported $S^{35}$-taurocholate. After protein precipitation with trichloroacetic acid, a portion of the supernatant liquid was extracted four times with ether (saturated with $0.1 \mathrm{~N} \mathrm{HCl}$ ). $\mathrm{A}_{\mathrm{p}}$ proximately $5.5 \mathrm{mg}$ nonradioactive taurine was added to the aqueous phase, which was then evaporated at $40^{\circ} \mathrm{C}$ under a stream of air. The residue was taken up in 5 $\mathrm{ml}$ 98\% ethanol, and, after centrifugation, the supernatant fluid was assayed for radioactivity and the concentration of taurocholate determined chemically.

Estimation of specific activity of transported $C^{\mathbf{1 4}}-g l y-$ cine-labeled glycocholate. Protein was precipitated by immersion of the specimen for 10 minutes in boiling water. The supernatant fluid was decanted and acidified; after addition of excess nonradioactive glycine, a portion of the supernatant liquid was extracted with ether. The ether fraction was subsequently evaporated and the residue redissolved in absolute ethanol. The glycocholic acid (dissolved in the supernatant fluid) was then assayed for radioactivity and its concentration determined chemically; thin-layer chromatography did not demonstrate any contamination with cholic or taurocholic acids.

Analysis for $C^{14}$-glycine. In experiments designed to determine if there was hydrolysis of glycine-labeled glycocholate during its transport through an everted sac, it was necessary to assay the serosal fluid for $C^{\mathbf{1 4}}$-glycine after removal of all radioactive glycocholate. After 
TABLE I

Transport of sodium taurocholate by everted rat intestinal sacs*

\begin{tabular}{|c|c|c|c|c|}
\hline \multirow[b]{2}{*}{ Region of intestine } & \multirow{2}{*}{$\begin{array}{l}\text { Mucosal taurocholate } \\
\text { concentration before } \\
\text { incubation }\end{array}$} & \multirow{2}{*}{$\begin{array}{c}\text { Mucosal taurocholate } \\
\text { concentration after } \\
\text { incubation }\end{array}$} & \multicolumn{2}{|c|}{$\begin{array}{l}\text { Serosal bile salt concentration } \\
\text { after incubation }\end{array}$} \\
\hline & & & Taurocholate & Cholate \\
\hline & & mumoles per $m l$ & & \\
\hline Jejunum & $\begin{array}{r}0 \\
200 \\
200 \\
1,000 \\
1,000\end{array}$ & $\begin{array}{r}42 \\
240 \\
204 \\
986 \\
920\end{array}$ & $\begin{array}{r}36 \\
86 \\
86 \\
122 \\
148\end{array}$ & $\begin{array}{l}6 \\
0 \\
0 \\
4 \\
4\end{array}$ \\
\hline Ileum & $\begin{array}{r}0 \\
200 \\
200 \\
1,000 \\
1,000\end{array}$ & $\begin{array}{r}20 \\
50 \\
50 \\
660 \\
680\end{array}$ & $\begin{array}{r}58 \\
386 \\
478 \\
1,050 \\
476\end{array}$ & $\begin{array}{r}8 \\
20 \\
8 \\
2 \\
14\end{array}$ \\
\hline
\end{tabular}

* The mucosal medium in each experiment was $10 \mathrm{ml}$ Krebs-Ringer bicarbonate buffer containing $10 \mathrm{mg}$ glucose and taurocholate at the concentrations indicated. The sacs were $15 \mathrm{~cm}$ in length and were filled with $2 \mathrm{ml} \mathrm{Krebs-Ringer}$ bicarbonate solution containing $2 \mathrm{mg}$ glucose but no taurocholate. Incubations were carried out for 90 minutes at $37^{\circ} \mathrm{C}$, and the flasks were gassed continuously with $95 \%$ oxygen and $5 \%$ carbon dioxide.

precipitation of protein by heating to $100^{\circ} \mathrm{C}$ for $10 \mathrm{~min}$ utes, carrier glycine was added, and most of the bile salt was extracted into ether. The remainder of the glycocholate was removed by extraction into butanol, and the glycine was left in aqueous solution. Controlled experiments showed that the separation of glycine and glycocholate was virtually complete and that the glycine recovery exceeded $95 \%$; high voltage electrophoresis confirmed the absence of radioactive glycine contaminant in the glycocholate fraction.

\section{Results}

Experiments to determine if conjugated bile salts are hydrolyzed during transport

1) Taurocholate. Everted intestinal sacs were incubated with sodium taurocholate and the serosal fluid analyzed chemically for cholate and for taurocholate. The results in Table I show active trasport of taurocholate by the rat ileum; in the two experiments with the lower bile salt concentration, the final ratios between serosal and mucosal concentrations ( $\mathrm{S} / \mathrm{M}$ ratios) were 7.7 and 9.6, respectively. No significant amounts of cholate were demonstrated in the serosal fluid, and results with sacs prepared from hamster ileum were similar. Sacs prepared from the jejunum did not demonstrate active transport of taurocholate. These findings concerning the site of bile salt transport are consistent with previous work (3).

The possibility remained that taurocholate was split and then reconjugated during its passage through the wall of the everted sac. This was investigated by determining the specific activity of $\mathrm{S}^{35}$-taurocholate transported in the presence and absence of nonradioactive taurine. In other experiments we observed that part of the taurine was transported during these experimental conditions and that these concentrations of taurine did not inhibit the transport of cholate or taurocholate. The absence of an alteration in specific activity excludes significant hydrolysis and re-

TABLE II

Specific activity of $S^{35}$-taurocholate transported by everted ileal sacs in the presence of taurine*

\begin{tabular}{|c|c|c|c|c|}
\hline \multirow[b]{2}{*}{ Animal } & \multirow{2}{*}{$\begin{array}{c}\text { Initial } \\
\text { mucosal } \\
\text { taurine } \\
\text { concentration }\end{array}$} & \multirow[b]{2}{*}{$\begin{array}{l}\text { No. of } \\
\text { observations }\end{array}$} & \multicolumn{2}{|c|}{$\begin{array}{c}\text { Specific activity } \\
\text { of transported } \\
\mathbf{S}^{25} \text {-taurocholate }\end{array}$} \\
\hline & & & Mean & $\begin{array}{l}\mathrm{SE} \text { or } \\
\text { range }\end{array}$ \\
\hline & umoles per $m l$ & & & \\
\hline Rat & $\begin{array}{l}0 \\
0.1 \\
1.0\end{array}$ & $\begin{array}{r}10 \\
8 \\
9\end{array}$ & $\begin{array}{l}75 \\
75 \\
73\end{array}$ & $\begin{array}{l} \pm 3.9 \ddagger \\
\pm 3.5 \\
\pm 4.0\end{array}$ \\
\hline Hamster & $\begin{array}{l}0 \\
0.2 \\
1.0 \\
4.0\end{array}$ & $\begin{array}{l}4 \\
3 \\
3 \\
4\end{array}$ & $\begin{array}{l}86 \\
88 \\
84 \\
88\end{array}$ & $\begin{array}{l}79-938 \\
86-91 \\
82-86 \\
84-93\end{array}$ \\
\hline
\end{tabular}

* The mucosal medium in each experiment was $10 \mathrm{ml}$ Krebs-Ringer bicarbonate buffer containing 2 m moles $3^{35}$-taurocholate, $10 \mathrm{mg}$ glucosé, and taurine in the concentrations indicated. Rat sacs were $15 \mathrm{~cm}$ in length; hamster sacs were $10 \mathrm{~cm}$. Each sac was filled with $2 \mathrm{ml}$ KrebsRinger bicarbonate buffer containing $2 \mathrm{mg}$ glucose but neither taurocholate nor taurine. Incubations were for 90 minutes at $37^{\circ} \mathrm{C}$.

+ Specific activity of $\mathrm{S}^{35}$-taurocholate in the serosal fluid after incubation is expressed as percentage of the specific activity of the substrate added initially to mucosal side.

$\ddagger \pm$ Standard error of the mean.

\& Range. 
synthesis of taurocholate (Table II). The consistently lower specific activity in the rat experiments is presumably due to this animal's lack of a gall bladder and the resultant greater dilution with endogenous nonradioactive taurocholate.

Homogenates prepared from rat and hamster intestinal mucosa were incubated with sodium taurocholate $(0.4 \mu$ mole per $\mathrm{ml})$ for 90 minutes and were then analyzed for cholate and taurocholate. No significant splitting of the conjugated bile salt was observed; the results of a typical experiment are given in Table III. In other experiments rat jejunal and ileal homogenates were incubated with a greater concentration of sodium taurocholate $(10 \mu$ moles per $\mathrm{ml})$, and demonstration of the liberation of free taurine was impossible. The accuracy of the taurine estimation was such that any hydrolysis in excess of $2 \%$ would have been detected.

2) Glycocholate. Everted ileal sacs from rat and hamster were incubated in Krebs-Ringer bicarbonate buffer containing $\mathrm{C}^{14}$-glycocholate (glycine-labeled) at a concentration of $0.43 \mu$ mole per $\mathrm{ml}$ and nonradioactive glycine at a concentration of $2.67 \mu$ moles per $\mathrm{ml}$. Each sac was filled with $2 \mathrm{ml}$ of buffer without labeled bile salt or glycine. After an incubation of 45 minutes the serosal fluid was analyzed for $\mathrm{C}^{\mathbf{1 4}}$-glycine and $\mathrm{C}^{\mathbf{1 4}}$ glycocholate. All the radioactivity in the serosal fluid was present in the conjugated bile salt fraction and none in free glycine. The sac walls were then homogenized and analyzed with the same

TABLE III

Incubation of mucosal homogenates with sodium taurocholate*

\begin{tabular}{llcr}
\hline \hline Animal & \multicolumn{1}{c}{$\begin{array}{c}\text { Description of } \\
\text { homogenate }\end{array}$} & \multicolumn{2}{c}{$\begin{array}{c}\text { Bile salt recovered } \\
\text { after incubation }\end{array}$} \\
\cline { 2 - 3 } Rat & Taurocholate & Cholate \\
& Ileal, heat inactivated $\dagger$ & 890 & 2 \\
& Ileal & 904 & 6 \\
Hamster & Jejunal & 800 & 0 \\
& Ileal, heat inactivated $\dagger$ & 770 & 0 \\
& Ileal & 776 & 12 \\
& Jejunal & 814 & 0
\end{tabular}

* The incubation medium consisted of $0.5 \mathrm{ml}$ homogenate, $800 \mathrm{~m} \mu$ moles sodium taurocholate, $4 \mathrm{mg}$ glucose, and $1.5 \mathrm{ml} 0.125 \mathrm{M}$ potassium phosphate buffer, $\mathrm{pH} 7.0$. The incubation was at $37^{\circ} \mathrm{C}$ for 90 minutes.

† Homogenate prepared from ileal mucosa was inactivated by immersion in boiling water for 15 minutes. result. The final $\mathrm{S} / \mathrm{M}$ ratio for the bile salt was 9.5 in the rat sac and 3.9 in the hamster sac. Parallel sac experiments were conducted with labeled glycine and nonradioactive glycocholate at the same concentrations. Glycine passed from the mucosal to the serosal side, but under these experimental conditions a concentration gradient was not established; the final $\mathrm{S} / \mathrm{M}$ ratios were 0.39 in the rat and 0.83 in the hamster. There was no exchange of label between the $\mathrm{C}^{14}$-glycine and the glycocholate.

In other experiments with everted sacs prepared from hamster ileum the specific activity of transported $\mathrm{C}^{\mathbf{1 4}}$-glycocholate (glycine-labeled) was determined and was found to be unaltered during the simultaneous transport of nonradioactive glycine. These data excluded the possibility that hydrolysis of glycocholate occurred at one stage of transport followed later by resynthesis of the conjugated bile salt.

\section{Transport of cholate}

Sacs from hamster ileum were incubated for 45 minutes in a medium containing sodium cholate in a concentration of $0.18 \mu$ mole per $\mathrm{ml}$ (there was no bile salt initially on the serosal side). Cholate accumulated in the serosal compartment, the final S/M ratio being approximately 2 . This concentration gradient is considerably lower than those found for taurocholate and glycocholate under similar conditions.

We wished to determine whether the intestinal mucosa was able to synthesize taurocholate when both cholate and taurine were present together. Everted hamster ileal sacs were incubated for 1 hour in media containing sodium cholate $(0.5$ $\mu$ mole per $\mathrm{ml}$ ) and taurine (1.0 $\mu$ mole per $\mathrm{ml}$ ). At the end of the incubation the serosal fluid was analyzed; the mean cholate concentration was 0.2 $\mu$ mole per $\mathrm{ml}$, and in each case there was only a trace of taurocholate in a concentration that did not exceed the levels found in control sacs incubated without added bile salts and taurine.

\section{Effect of inhibitors and of electrolytes on tauro- cholate transport}

Taurocholate transport by sacs of everted hamster ileum was studied in the absence of oxygen and in the presence of DNP and of ouabain. The re- 
TABLE IV

Inhibition of taurocholate transport across everted hamster ileal sacs*

\begin{tabular}{|c|c|c|c|}
\hline \multirow[b]{2}{*}{ Incubation conditions } & \multirow[b]{2}{*}{ No. of experiments } & \multicolumn{2}{|c|}{$\begin{array}{l}\text { Final taurocholate } \\
\text { concentration } \\
\text { in serosal fluid }\end{array}$} \\
\hline & & Mean & $\mathrm{SE}$ \\
\hline & & \multicolumn{2}{|c|}{ mumoles per $m l$} \\
\hline Control & 9 & 498 & \pm 34 \\
\hline Anoxia, $95 \% \mathrm{~N}_{2}, 5 \% \mathrm{CO}_{2}$ & 5 & 71 & \pm 8 \\
\hline $\mathrm{DNP}, 2.5 \times 10^{-3} \mathrm{M} \dagger$ & 5 & 215 & \pm 7 \\
\hline Ouabain, $3.4 \times 10^{-5} \mathrm{M}$ & 5 & 485 & \pm 20 \\
\hline 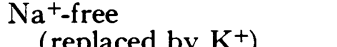 & 5 & 16 & +2 \\
\hline $\mathrm{Na}^{+}$-free & & 10 & \pm 2 \\
\hline$\left(\right.$ replaced by $\left.\mathrm{Li}^{+}\right)$ & 5 & 55 & \pm 7 \\
\hline
\end{tabular}

* The usual mucosal medium was $10 \mathrm{ml}$ Krebs-Ringer bicarbonate buffer containing $2 \mu$ moles sodium taurocholate and $10 \mathrm{mg}$ glucose. The sacs were $10 \mathrm{~cm}$ in length and were filled with $2 \mathrm{ml}$ Krebs-Ringer bicarbonate buffer containing $2 \mathrm{mg}$ glucose but neither taurocholate nor inhibitors. In the $\mathrm{Na}^{+}$-free experiments, $\mathrm{Na}^{+}$in both the mucosal medium and the serosal fluid was replaced by equimolar concentrations of either $\mathrm{K}^{+}$or $\mathrm{Li}^{+}$. Incubations were at $37^{\circ}$ for 45 minutes, and the flasks were gassed continuously with $95 \%$ oxygen and $5 \%$ carbon dioxide except as indicated above.

$\dagger \mathrm{DNP}=$ 2,4-dinitrophenol.

sults in Table IV indicate that both anoxia and $\mathrm{DNP}$ at a concentration of $2.5 \times 10^{-13} \mathrm{M}$ caused significant inhibition of taurocholate transport into the serosal medium. The amounts of bile salt retained in the sac walls were reduced proportionately. Results of transport in the presence

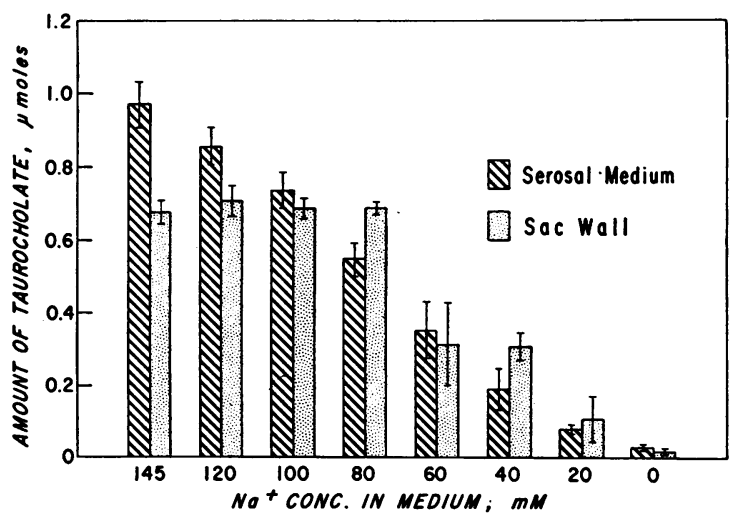

Fig. 1. Effect of $\mathrm{Na}^{+}$concentration on tauroCHOLATE TRANSPORT BY EVERTED SACS OF HAMSTER ILEUM. The incubation conditions were the same as described in Table IV. Variation of the $\mathrm{Na}^{+}$concentration in mucosal and serosal media was achieved by replacement of $\mathrm{Na}^{+}$by equimolar concentrations of $\mathrm{K}^{+}$. $\mathrm{Re}-$ sults at each $\mathrm{Na}^{+}$concentration level are means of 5 to 10 experiments; standard errors of the means are indicated by vertical lines. of ouabain at a concentration of $3.4 \times 10^{-5} \mathrm{M}$ did not differ significantly from control values (Table IV).

The omission of glucose from the incubation media or the addition of phloridzin $10^{-5} \mathrm{M}$ (a concentration that inhibits active transport of glucose) had no effect on taurocholate transport.

Striking results were noted when the electrolyte composition of the medium was altered. In a sodium-free medium, where the $\mathrm{Na}^{+}$was replaced by $\mathrm{K}^{+}$, practically no taurocholate reached the serosal side. When $\mathrm{Li}^{+}$replaced $\mathrm{Na}^{+}$, the final serosal concentration of bile salt was slightly greater (Table IV). The absence of calcium and magnesium, either individually or together, did not affect taurocholate transport.

The dramatic influence of sodium ions was further studied in a series of experiments in media with varying sodium concentrations and in which the replacing ion was potassium. Figure 1 shows that as the $\mathrm{Na}^{+}$concentration was reduced, there was a progressive decrease in the serosal accumulation of taurocholate; there was, however, no in-

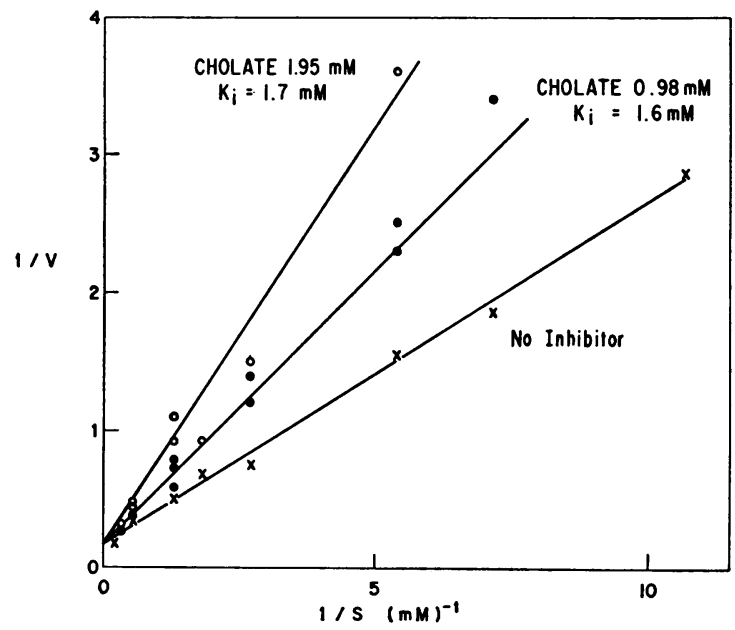

Fig. 2. Transport of $\mathrm{S}^{35}$-taurocholate by HAMSTER ILEAL SACS IN PRESENCE AND ABSENCE OF SODIUM CHOLATE (Lineweaver-Burk plots). Incubation conditions were the same as described in Table IV except that the taurocholate concentrations in the mucosal media ranged from 0.1 to $7.4 \mathrm{mM} .1 / \mathrm{S}$ is the reciprocal of the initial taurocholate concentration. $1 / \mathrm{V}$ is the reciprocal of the amount of $\mathrm{S}^{35}$-taurocholate disappearing from the mucosal medium. The lowermost line is for uninhibited taurocholate transport; each point is the mean of 2 to 8 experiments. The upper two lines are for taurocholate transport in the presence of sodium cholate; each point is the result of one experiment. 
hibition of bile salt uptake into the sac wall until the $\mathrm{Na}^{+}$concentration was below $80 \mathrm{mM}$.

\section{Kinetic studies of bile salt transport}

Transport of $\mathrm{S}^{35}$-taurocholate was studied in hamster ileal sacs, the initial bile salt concentration on the mucosal side ranging from 0.1 to 7.4 $\mathrm{mM}$. Absorption was measured by the disappearance of radioactivity from the mucosal compartment over a 45-minute incubation and was plotted in reciprocal form against the reciprocal of the original substrate concentration [Lineweaver and Burk plot (18)]. The results fall on a straight line, suggesting that absorption of taurocholate conforms to the pattern of saturation kinetics described by Michaelis and Menten (19). The regression line for results from 46 experiments was calculated by the least squares method, and the apparent $\mathrm{Km}$ (half maximal concentration) was found to be $1.34 \mathrm{mM}$ (Figure 2) and the $\mathrm{V} \max$ (apparent limiting velocity of absorption), $10.9 \mu$ moles for a $10-\mathrm{cm}$ sac incubated 45 minutes. By the same method the $\mathrm{Km}$ values for sodium cholate and for sodium glycocholate were $1.95 \mathrm{mM}$ and $0.90 \mathrm{mM}$, respectively. The use of initial substrate concentration uncorrected for the fall in concentration during absorption is common practice and has been justified mathematically by Fisher and Parsons (20); however, the calcu-

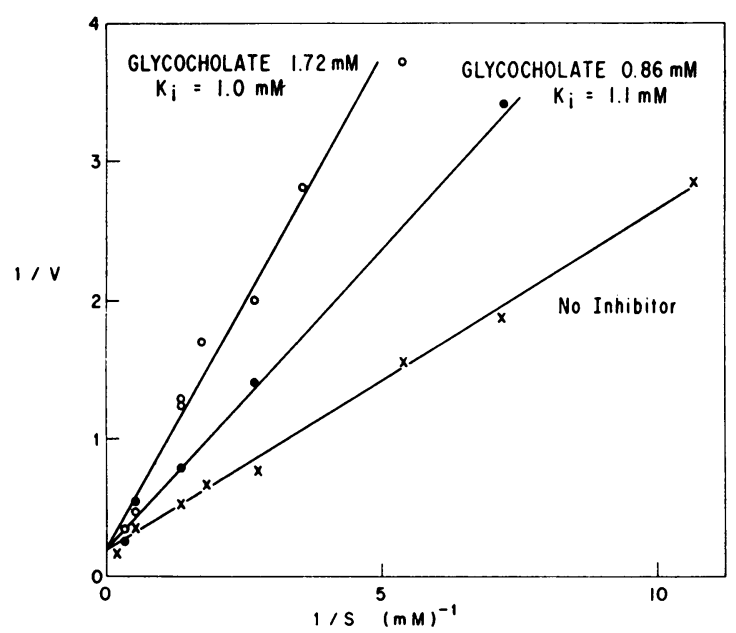

Fig. 3. Transport of $\mathrm{S}^{35}$-TAUROCholate by haMSTER ILEAL SACS IN PRESENCE AND ABSENCE OF SODIUM GLYCOCHOLATE (Lineweaver-Burk plots). The experimental conditions were the same as described in Figure 2 except that the inhibiting bile salt was sodium glycocholate. lated value for the $\mathrm{Km}$ is different if the correction is made.

When sodium cholate or sodium glycocholate was in the mucosal medium together with $\mathrm{S}^{35}$ taurocholate, there was definite inhibition of taurocholate absorption by the everted sacs. Double reciprocal plots were drawn for taurocholate absorption in the presence of each of the two bile salts at two concentration levels (Figures 2 and 3 ). These values evidently tend to fall on straight lines which, when extrapolated, intersect the $y$-axis at or close to the point where it is crossed by the regression line for uninhibited taurocholate transport.

These results, therefore, are consistent with competitive rather than noncompetitive inhibition. The $K_{i}$ values for cholate and glycocholate (each at two concentration levels) were calculated from the experimental data by assuming that they are competitive inhibitors of taurocholate transport and that the $\mathrm{Km}$ for taurocholate is $1.34 \mathrm{mM}$ (Figures 2 and 3 ).

\section{Discussion}

Studies on the enterohepatic circulation of bile salts have indicated that their reabsorption from the intestine is very efficient. For example, in a normal $200-\mathrm{g}$ rat, the bile acid pool of $20 \mathrm{mg}$ has been calculated to circulate about ten times each day; only about $5 \mathrm{mg}$ remains unabsorbed and is excreted in the feces after modification by the bacteria of the large intestine $(2,21)$.

The bile acids, as excreted by the liver, are conjugated with glycine or taurine, and in most species these compounds remain unhydrolyzed while within the lumen of the small intestine (22). The conjugated bile salts are water soluble but have a molecular size too large to be absorbed by diffusion through membrane pores (23). The $\mathrm{pH}$ of intestinal contents is such that the bile salts are for all practical purposes fully ionized, thus making unlikely any significant absorption by a mechanism involving the solution of the undissociated acid in the lipid components of the mucosal cell membrane [the pKa of taurocholic acid is 1.54 and of glycocholic acid 4.54 (24)]. We chose sodium taurocholate for particular study because the limited lipid solubility and low pKa of the free acid suggested that its absorption would be more dependent on a specific transport mecha- 
nism. With regard to our in vitro data, we might note that the $\mathrm{pH}$ gradient across everted ileal sacs from the hamster would favor accumulation of a weak acid on the mucosal and not on the serosal side (25).

It has been recognized recently that the absorption of many compounds is accompanied by their metabolic modification at the surface of the mucosal cell or within the cell. For example, hydrolysis or esterification is important in the absorption of disaccharides (26), peptides (27), and lipids (28). In everted gut sacs some steroid hormones and thyroxine analogues have been shown to appear on the serosal side as conjugates of glucuronic acid (29-31). A reverse type of mechanism exists in the case of the water soluble bilirubin diglucuronide, which appears not to be absorbed as such but only after hydrolysis to the lipid soluble free bilirubin $(32,33)$. There is some evidence in rats to suggest that this hydrolysis takes place at the mucosal cell surface rather than in the intestinal lumen (32).

Active transport of conjugated bile salts has previously been demonstrated in the ileum (3), although there have been no data on the possibility of hydrolysis during absorption. In everted ileal sacs from the rat and the hamster, we have confirmed the presence of a mechanism for the transport of taurocholate, glycocholate, and cholate against a concentration gradient; this property was absent in jejunal sacs. We were unable to demonstrate the hydrolysis of either taurocholate or glycocholate during its transport. Likewise the possibility of hydrolysis followed by reconjugation has been excluded. Confirmatory experiments with mucosal homogenates failed to demonstrate a hydrolytic mechanism (peptidase) for the conjugated bile salts. Therefore, the active transport of the conjugated bile salts studied clearly does not depend on their metabolic modification by hydrolysis.

Absence of sodium ions has been shown to inhibit the intestinal active transport of monosaccharides $(34-6)$, amino acids $(37,38)$, pyrimidines (37), and more recently inorganic phosphate ions (38); indeed the effect is not limited to the intestine but has been demonstrated in other tissues such as the kidney (39). Studies of sugar transport into strips of hamster intestine have led Crane, Bihler, and Hawkins to postulate that glucose enters the mucosal cell as a $\mathrm{Na}^{+}$ glucose-carrier complex which then dissociates inside the cell, the $\mathrm{Na}^{+}$being removed immediately from the cell interior by a $\mathrm{Na}^{+}$pump $(40,41)$. They suggested that the inhibitory effects of cardiac glycosides, anoxia, and dinitrocresol are due to a failure of the $\mathrm{Na}^{+}$pump, such that although glucose could still enter and leave the mucosal cell freely (coupled with $\mathrm{Na}^{+}$and carrier), no uphill gradient could be established.

In our experiments with taurocholate, the result of replacing $\mathrm{Na}^{+}$in the medium by $\mathrm{K}^{+}$was striking. Under these conditions virtually no taurocholate appeared in the sac wall or in the serosal compartment. The use of $\mathrm{Li}^{+}$as the replacing ion was associated with somewhat less inhibition; a similar difference between the effects of $\mathrm{K}^{+}$and $\mathrm{Li}^{+}$media was noted by Bihler and Crane in the case of sugar transport (35). When the incubations were carried out with $\mathrm{Na}^{+}$but under anoxic conditions or in the presence of DNP, taurocholate entered the sac wall and passed to the mucosal side, but it was not concentrated. Ouabain, which in low concentration is considered to be primarily an inhibitor of $\mathrm{Na}^{+}$ transport (42), has been shown to depress the transfer of sugars and of amino acids $(43,44)$, but we did not find a significant effect on taurocholate transport. In accord with the conclusions of Crane in regard to glucose transport, our data suggest that sodium ions are necessary for the nonenergy dependent entry of taurocholate into mucosal cells, whereas the subsequent intracellular and serosal accumulation against a concentration gradient requires both $\mathrm{Na}^{+}$and energy.

When we used incubation media with gradually diminishing $\mathrm{Na}^{+}$concentration, there was a progressive decrease in the serosal accumulation of taurocholate (Figure 1). There was no inhibition of taurocholate uptake in the sac wall until the $\mathrm{Na}^{+}$concentration fell below $80 \mathrm{mM}$. Although assessing the significance of this finding is difficult at present, it is possible that sodium deprivation acts at two points: 1) at the site of entry of the bile salt into the mucosal cells and 2) at some point in the transport of taurocholate from the mucosa to the serosal compartment. Thus, at moderate reductions of $\mathrm{Na}^{+}$concentration, the concentration gradient achieved between the tissues of the sac wall and the mucosal medium is 
virtually normal, but there is a significant inhibition of taurocholate transport into the serosal fluid.

Sodium ions are themselves actively transported by the small intestine, and the normal potential difference between mucosal and serosal surfaces can be explained on this basis (45). The membrane charge is diminished in the presence of low mucosal $\mathrm{Na}^{+}$concentration or in the absence of a sugar that can be actively transported (46). The magnitude of the electrical gradient is lowest in the ileum (45), and whether it can play a significant role in assisting taurocholate transport is doubtful. However, the transport of the large bile salt anion with $\mathrm{Na}^{+}$as an ion pair is quite possible.

Since the active transport of a large number of substances, mostly nonelectrolytes, is dependent on the presence of $\mathrm{Na}^{+}$, the association is probably a fundamental one (47). A promising approach is suggested by the $\mathrm{Mg}^{++}$dependent $\left(\mathrm{Na}^{+}\right.$ $+\mathrm{K}^{+}$-activated) membrane, adenosine triphosphatase (ATPase), which was first demonstrated by Skou in crab nerve (48). This enzyme has been found in a number of tissues (49) and in experiments on unfragmented red cell ghosts has been shown to be part of a coupled transport system for $\mathrm{Na}^{+}$and $\mathrm{K}^{+}$, activated inside the cells by $\mathrm{Na}^{+}$and outside by $\mathrm{K}^{+}(50)$. One can speculate that in the intestine a $\mathrm{Na}^{+}$-activated membrane, ATPase, may provide the metabolic energy for a number of different carrier-mediated transport systems including the one for taurocholate.

That the transport of taurocholate, cholate, and glycocholate obeyed Michaelis-Menten kinetics is consistent with the hypothesis that the rate-limiting factor in the absorption of each compound is its combination with a membrane carrier molecule. Cholate and glycocholate were found to cause reversible inhibition of taurocholate transport, and their $\mathrm{Ki}$ values at two concentration levels corresponded reasonably well with their respective $\mathrm{Km}$ determinations when they were transported alone. These data suggest that the three bile salts share the same active transport pathway. Although this type of evidence has been widely used to specify the absorption characteristics of many compounds, it must be recognized that the assumptions involved in the derivation of the Michaelis-Menten equation are valid only in relatively simple purified enzyme systems, and one must hesitate before concluding that these same assumptions also apply in the much more complex process of intestinal absorption $(51,52)$. Furthermore, transport by mechanisms unrelated to membrane carriers can in some circumstances show saturation and competition kinetics (53).

Lack and Weiner have already shown mutual inhibition of transport by a number of bile acids (4), but interpretation is difficult because many of these compounds, particularly the unconjugated mono- and dihydroxy bile acids are toxic to the intestinal mucosa and depress absorption generally (4).

Further information on the structural specificity of the transport system for bile salts is important because they are the major end products of cholesterol metabolism. Inhibition of their reabsorption from the intestine might therefore be expected to result in increased conversion of cholesterol to bile salts and a diminution of the cholesterol pool. In some species of animals and in man, hypocholesterolemia has been shown to follow the oral administration of an intestinal bile salt sequestrant such as cholestyramine (54), but steatorrhea is a frequent complication. It is theoretically possible that a structural analogue of the bile salts may cause a specific block in their ileal reabsorption yet not interfere with their function in fat digestion and absorption.

\section{Summary}

1. The transport of taurocholate, glycocholate, and cholate has been studied with everted intestinal sacs from the hamster and the rat. The presence in the ileum of an active transport mechanism (transport against a concentration gradient), and its absence in the jejunum, have been confirmed.

2. No evidence was found for hydrolysis of the conjugated bile salts during the process of absorption, nor were they hydrolyzed after incubation with homogenates of intestinal mucosa. Conversely, when cholate transport was studied in the presence of excess taurine, there was no evidence of taurocholate synthesis by the mucosa.

3. In the absence of $\mathrm{Na}^{+}$in the mucosal medium, taurocholate transport was markedly inhibited, and this inhibition was greater than that caused by anoxia or by dinitrophenol. An apparent dissociation was noted between the effects of $\mathrm{Na}^{+}$ 
deprivation on taurocholate accumulation in the sac wall and in the serosal fluid medium. The relationship of $\mathrm{Na}^{+}$and bile salt transport was discussed. The participation of a $\mathrm{Na}^{+}$-activated membrane adenosine triphosphatase may be operative in the taurocholate active transport mechanism.

4. Transport of taurocholate, cholate, and glycocholate was shown to obey Michaelis-Menten (saturation) kinetics, and there was evidence that cholate and glycocholate are competitive inhibitors of taurocholate transport. We suggest that taurocholate, glycocholate, and cholate share the same transport mechanism.

\section{Acknowledgments}

The authors are indebted to Miss Dorothy Budz and to Mrs. Marilyn Kozacko for valuable technical assistance.

\section{References}

1. Wilson, J. D., and M. D. Siperstein. Effect of saturated and unsaturated fats on fecal excretion of end products of cholesterol-4-C ${ }^{14}$ metabolism in the rat. Amer. J. Physiol. 1959, 196, 596.

2. Bergström, S. Metabolism of bile acids. Fed. Proc. (suppl. 11) 1962, 21, 28.

3. Lack, L., and I. M. Weiner. In vitro absorption of bile salts by small intestine of rats and guinea pigs. Amer. J. Physiol. 1961, 200, 313.

4. Lack, L., and I. M. Weiner. Intestinal absorption of bile salts and some biological implications. Fed. Proc. 1963, 22, 1334.

5. Weiner, I. M., and L. Lack. Absorption of bile salts from the small intestine in vivo. Amer. J. Physiol. 1962, 202, 155.

6. Playoust, M. R., I. M. Weiner, and L. Lack. The effects of intestinal resection on bile salt absorption in dogs. In preparation.

7. Hofmann, A. F. Thin-layer adsorption chromatography of free and conjugated bile acids on silicic acid. J. Lipid Res. 1962, 3, 127.

8. Norman, A. Preparation of conjugated bile salts using mixed carboxylic acid anhydrides. Arkiv Kemi 1955, 8, 331.

9. Hammarsten, O. Ueber Dehydrocholalsäure, ein neues Oxydations-produkt der Cholalsäure. Ber. $1881,14,71$.

10. Bergström, S., and A. Norman. Synthesis of conjugated bile acids. Bile acids and steroids 5. Acta chem. scand. 1953, 7, 1126.

11. Norman, A. Separation of conjugated bile acids by partition chromatography. Bile acids and steroids 6. Acta chem. scand. 1953, 7, 1413.

12. Katz, A. M., W. J. Dreyer, and C. B. Anfinsen. Peptide separation by two-dimensional chromatography and electrophoresis. J. biol. Chem. 1959, 234, 2897.

13. Irvin, J. L., C. G. Johnston, and J. Kopala. A photometric method for the determination of cholates in bile and blood. J. biol. Chem. 1944, 153, 439.

14. Pentz, E. I., C. H. Davenport, W. Glover, and D. D. Smith. A test for the determination of taurine in urine. J. biol. Chem. 1957, 228, 433.

15. Wilson, T. H., and G. Wiseman. The use of sacs of everted small intestine for the study of transference of substances from the mucosal to the serosal surface. J. Physiol. 1954, 123, 116.

16. Cohen, P. P. Methods for preparation and study of tissues in Manometric Techniques, W. W. Umbreit, R. H. Burris, and J. F. Stauffer, Eds. Minneapolis, Burgess, 1959, p. 149.

17. Senior, J. R., and K. J. Isselbacher. Direct esterification of monoglycerides with palmityl coenzyme A by intestinal epithelial subcellular fractions. J. biol. Chem. 1962, 237, 1454.

18. Lineweaver, H., and D. Burk. The determination of enzyme dissociation constants. J. Amer. chem. Soc. 1934, 56, 658.

19. Michaelis, L., and M. L. Menten. Die Kinetic der Invertinwirkung. Biochem. Z. 1913, 49, 333.

20. Fisher, R. B., and D. S. Parsons. Glucose movements across the wall of the rat small intestine. J. Physiol. 1953, 119, 210.

21. Gustafsson, B. E., A Norman, and J. Sjövall. Influence of E. coli infection on turnover and metabolism of cholic acid in germ-free rats. Arch. Biochem. 1960, 91, 93.

22. Bergström, S., H. Danielsson, and B. Samuelsson. Formation and metabolism of bile acids in Lipide Metabolism, K. Bloch, Ed. New York, John Wiley and Sons, 1960, p. 291.

23. Wilson, T. H. Intestinal Absorption. Philadelphia, W. B. Saunders, 1962, p. 43.

24. Sobotka, H. Chemistry of the Steroids. Baltimore, Williams and Wilkins, 1938.

25. Wilson, T. H., and L. Kazyak. Acid-base changes across the wall of hamster and rat intestine. Biochim. biophys. Acta (Amst.) 1957, 24, 124.

26. Miller, D., and R. K. Crane. The digestive function of the epithelium of the small intestine. I. An intracellular locus of disaccharide and sugar phosphate ester hydrolysis. Biochim. biophys. Acta (Amst.) 1961, 52, 281.

27. Newey, H., and D. H. Smyth. Intracellular hydrolysis of dipeptides during intestinal absorption. J. Physiol. 1960, 152, 367.

28. Isselbacher, K. J. Fat absorption and the esterification of fatty acids by intestinal mucosa. Gastroenterology 1961, 40, 259.

29. Tapley, D. F., R. Herz, Jr., J. E. Ross, T. F. Deuel, and L. Leventer. Glucuronide formation in the active transport of amino acid and thyroxine analogues by rat intestine. Biochim. biophys. Acta (Amst.) 1960, 43, 344. 
30. Herz, R., Jr., D. F. Tapley, and J. E. Ross. Glucuronide formation in the transport of thyroxine analogues by rat intestine. Biochim. biophys. Acta (Amst.) 1961, 53, 273.

31. Smith, F. R., D. F. Tapley, and J. E. Ross. Glucuronide formation in the transport of estradiol by rat intestine in vitro. Biochim. biophys. Acta (Amst.) 1963, 69, 68.

32. Lester, R., and R. Schmid. Intestinal absorption of bile pigments. I. The enterohepatic circulation of bilirubin in the rat. J. clin. Invest. 1963, 42, 736.

33. Lester, R., and R. Schmid. Intestinal absorption of bile pigments. II. Bilirubin absorption in man. New Engl. J. Med. 1963, 269, 178.

34. Riklis, E., and J. H. Quastel. Effects of cations on sugar absorption by isolated surviving guinea pig intestine. Canad. J. Biochem. 1958, 36, 347.

35. Bihler, I., and R. K. Crane. Studies on the mechanism of intestinal absorption of sugars. V. The influence of several cations and anions on the active transport of sugars, in vitro, by various preparations of hamster small intestine. Biochim. biophys. Acta (Amst.) 1962, 59, 78.

36. Faust, R. G. The effect of anoxia and lithium ions on the absorption of D-glucose by the rat jejunum, in vitro. Biochem. biophys. Acta (Amst.) 1962, $60,604$.

37. Czáky, T. Z. Significance of sodium ions in active intestinal transport of nonelectrolytes. Amer. J. Physiol. 1961, 201, 999.

38. Harrison, H. E., and H. C. Harrison. Sodium, potassium, and intestinal transport of glucose, L-tyrosine, phosphate, and calcium. Amer. J. Physiol. 1963, 205, 107.

39. Kleinzeller, A., and A. Kotyk. Cations and transport of galactose in kidney-cortex slices. Biochim. biophys. Acta (Amst.) 1961, 54, 367.

40. Bihler, I., K. A. Hawkins, and R. K. Crane. Studies on the mechanism of intestinal absorption of sugars. VI. The specificity and other properties of $\mathrm{Na}^{+}$-dependent entrance of sugars into intestinal tissue under anaerobic conditions, in vitro. Biochim. biophys. Acta (Amst.) 1962, 59, 94.

41. Crane, R. K. Hypothesis for mechanism of intestinal active transport of sugars. Fed. Proc. 1962, 21, 891.
42. Schatzmann, H.-J. Herzglykoside als Hemmstoffe für den aktiven Kalium- and Natriumtransport durch die Erthrocytenmembran. Helv. physiol. pharmacol. Acta 1953, 11, 346.

43. Csáky, T. Z. Effect of cardiac glycosides on the active biological transport of non-electrolytes (abstract). Biochem. Pharmacol. 1961, 8, 38.

44. Csáky, T. Z., H. G. Hartzog III, and G. W. Fernald. Effect of digitalis on active intestinal sugar transport. Amer. J. Physiol. 1961, 200, 459.

45. Clarkson, T. W., A. C. Cross, and S. R. Toole. Electrical potentials across isolated small intestine of the rat. Amer. J. Physiol. 1961, 200, 1233.

46. Schultz, S. G., and R. Zalusky. The interaction between active sodium transport and active sugar transport in the isolated rabbit ileum. Biochim. biophys. Acta (Amst.) 1963, 71, 503.

47. Csáky, T. Z. A possible link between active transport of electrolytes and nonelectrolytes. Fed. Proc. 1963, 22, 3.

48. Skou, J. C. Further investigations on a $\mathrm{Mg}^{++}+\mathrm{Na}^{+}-$ activated adenosinetriphosphatase, possibly related to the active, linked transport of $\mathrm{Na}^{+}$and $\mathrm{K}^{+}$ across the nerve membrane. Biochim. biophys. Acta (Amst.) 1960, 42, 6.

49. Bonting, S. L., K. A. Simon, and N. M. Hawkins. Studies on sodium-potassium-activated adenosine triphosphatase. I. Quantitative distribution in several tissues of the cat. Arch. Biochem. 1961, 95, 416.

50. Whittam, R. The asymmetrical stimulation of a membrane adenosine triphosphatase in relation to active cation transport. Biochem. J. 1962, 84, 110.

51. Wilbrandt, W., and T. Rosenberg. The concept of carrier transport and its corollaries in pharmacology. Pharmacol. Rev. 1961, 13, 109.

52. Wilson, T. H. Intestinal Absorption. Philadelphia, W. B. Saunders, 1962, p. 83.

53. Zierler, K. L. A model of a poorly-permeable membrane as an alternative to the carrier hypothesis of cell membrane penetration. Bull. Johns Hopk. Hosp. 1961, 109, 35.

54. Tennent, D. M., S. A. Hashim, and T. B. Van Itallie. Bile-acid sequestrants and lipid metabolism. Fed. Proc. (suppl. 11) 1962, 21, 77. 